\title{
Agricultural, forestry, textile and food waste used in the manufacture of biomass briquettes: a review
}

\author{
Teófilo Espinoza-Tellez ${ }^{1, *}{ }^{\mathbb{D}}$; José Bastías Montes ${ }^{2} \mathbb{D D}^{\mathbb{D}}$; Roberto Quevedo-León ${ }^{1} \mathbb{D}^{\mathbb{D}}$; Emir \\ Valencia-Aguilar $^{1} \mathbb{D} ;$ Haroldo Aburto Vargas ${ }^{1} \mathbb{D D}^{\mathbb{D}}$; Dagoberto Díaz-Guineo ${ }^{1 \mathbb{D}}$; Miguel \\ Ibarra-Garnica1 ${ }^{\mathbb{D}}$; Oscar Díaz-Carrasco ${ }^{1}$ (D)
}

1 Departamento de Acuicultura y Recursos Agroalimentarios, Programa Fitogen, Universidad de Los Lagos, Av. Alberto Fuchslocher 1305, Región de los Lagos, Osorno, Chile.

2 Departamento Ingeniería en Alimentos, Universidad del Bío-Bío, Av. Andrés Bello 720, Chillán, Chile.

Received March 8, 2020. Accepted July 5, 2020.

\begin{abstract}
In recent decades there has been a considerable global increase in urban population, industrial productivity, energy demand, waste generation, and the emission of greenhouse gases from energy conversion. The agricultural, forestry, textile and food sectors generate large amounts of waste and their environmental impact has become a major cause for concern in societies around the world. Current efforts are concerned with maximization of combustion efficiency and energy-related processes in general by making use of industrial residues and reducing particulate matter. The present review addresses the availability of different types of biomass that can be used to produce renewable energy and focuses on agricultural, forestry, urban and industrial residues. It also provides a description of the physical and calorific characteristics of the various raw materials available for the manufacture of briquettes and other fossil fuel alternatives.
\end{abstract}

Keywords: agriculture; waste; energy; biomass; briquette; pellet.

\section{Introduction}

Social progress is based on the consumption of large quantities of energy and most of this energy is obtained from the burning of fossil fuels such as coal and oil. Globally, $65 \%$ of all primary energy consumed comes from fossil fuels (Arias and López, 2015). Although these non-renewable forms of energy have accelerated humanity's technological development, they have the disadvantage of generating environmental pollution (Sari et al., 2019). Unrestrained consumption of these finite and non-renewable resources is now driving a need for new environmentally sustainable sources of energy. Examples of these new sources include industrial residues which are not only renewable but have the potential to replace fossil fuels ( $\mathrm{Ji}$ et al., 2018). In fact, in recent years, hydrocarbons are increasingly being substituted for new, sustainable energy sources (Anggono et al., 2018; Hernandez et al., 2015; Pandey, 2019), a move motivated by growth in both industrial and domestic energy demand (Alarenan et al., 2020; Wu and Lee, 2020). Fossil fuel importing countries are becoming increasingly interested in reducing their oil consumption (Musa et al., 2018), and states, industries and consumers must now fully confront the need for renewable alternatives (Karner et al., 2017).

The energy strategies of first world countries now include projects to incorporate first and second generation biomass into renewable energy production (CampuzanoDuque et al., 2016). Biomass has become an important energy resource thanks to its low production cost (Amarasekara et al., 2017; Ludevese-Pascual et al., 2016; Manzoor et al., 2017) and its chemical, physical and,

Cite this article:

Espinoza-Tellez, T.; Bastías, J.; Quevedo-León, R.; Valencia-Aguilar, E.; Aburto, H.; Díaz-Guineo, D.; Ibarra-Garnica, M; Diaz-Carrasco, O. 2020. Agricultural, forestry, textile and food waste used in the manufacture of biomass briquettes: a review. Scientia Agropecuaria 11(3): 427-437. 
most importantly, calorific properties, and may constitute a viable alternative to coal for industrial energy generation and heating (Balasubramani et al., 2016). Furthermore, a move to biomass incineration may help to reduce overall greenhouse and acidic gas emissions (Kayo et al., 2016; Martinez et al., 2020; Murphy et al., 2016). Such a change would require adaptations to the energy supply chain in order to facilitate waste selection, homogenization and storage in order to ensure the availability of sufficient quantities to sustain the production process (Balasubramani et al., 2016; Busov, 2018; Robles et al., 2018; Rojas et al., 2018b). As such, protocols would need to be developed within the various productive sectors for recycling and the manufacture of new energy sources from the available biomass (Ahmad et al., 2020; Jain and Kalamdhad, 2020; Jalgaonkar et al., 2020; Verma and Kumar, 2020). Different industries produce different forms of waste which may be suitable for the production of biofuels and the generation of bioenergy (Go et al., 2019). Waste from the agricultural, forestry, textile and food sectors can be used to manufacture biofuel briquettes (Hansted et al., 2016; Romallosa and Kraft, 2017; Vargas and Pérez, 2018), and experimental examples range from the creation of solid fuel from fly ash (Guo and Zhang, 2020; Makela et al., 2016) to the combination of rice husks and pine sawdust (Nino et al., 2020). Energy can be generated from the incineration of a wide variety of biomass residues. Types of waste most commonly used are those generated by agriculture (e.g., seed husks, almond hulls, olive stones, grass), timber (e.g., wood chips, shavings, sawdust), food production (e.g., processing residues), the textile industry (e.g., clothing, shoes), along with those produced by forestry (e.g., pruning, cleaning) and the cultivation of woody crops (e.g., pruning, uprooting, fallen trees). In general, these forms of waste can be transformed into briquettes, chips or pellets (Patil, 2019).

\section{Non-fossil fuel alternatives manufac- tured from waste}

\subsection{Briquettes}

Briquettes are generally produced by the combination and compaction of lignocellulosic biomass in the form of organic raw materials (Arias and López, 2015). These include wood chips and shavings; different types of agricultural, textile and food waste (Hoyos et al., 2019; Rodriguez et al., 2017); residues from the production of timber, wooden panels, furniture and other products; industrial biomass residues, urban biomass residues
(Sawadogo et al., 2018) and charcoal (Riuji et al., 2016). Briquetting results in a final product that has a greater density than its constituent materials. The process is also known as densification and has several advantages. Briquettes offer a superior spaceto-weight ratio than chopped wood or chips, making transportation more efficient. Briquetting also reduces the moisture content of the material to less than $12 \%$. Briquettes come in different shapes, but the majority are cylindrical with diameters ranging from 2 to $20 \mathrm{~cm}$ and lengths of between 15 and $50 \mathrm{~cm}$. The thermal conductivity coefficient of briquettes is higher than that of wood: as a compacted material, it contains less air, which slows combustion. Heating potential depends on aspects such as shape, moisture content, density, calorific value and thermal conductivity coefficient (Martín, 2014).

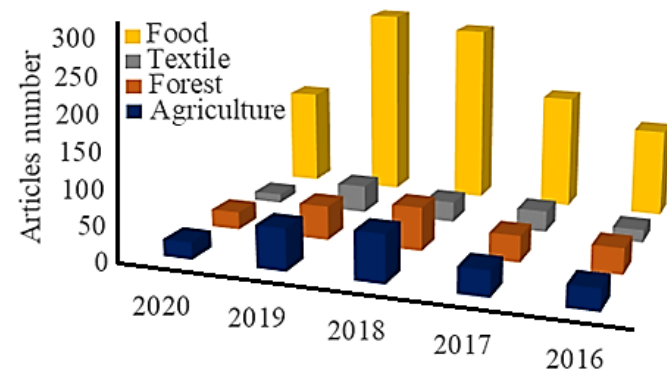

Figure 1. Published works concerning use of agricultural, forestry, textile, and food sector residues in the manufacture of briquettes. (The research was searched in the SCOPUS database and Web of Science, with the keywords: briquette; pellets; waste; biomass).

Given their physical, chemical and calorific properties, their ease of combustion, low humidity and high density, biomass briquettes represent an attractive form of biofuel for heating applications and the generation of electricity (Gangil, 2015; Tomeleri et al., 2017; Yank et al., 2016). The different raw materials used in the manufacture of briquettes produce different mechanical properties (Aransiola et al., 2019; Nhuchhen and Afzal, 2017). Different binding agents allow the production of briquettes of diverse shapes and sizes, and with varying degrees of firmness, compression, density, porosity, and other physical characteristics Briquetting also helps to minimize ash residue and improve other environmental aspects (Berastegui et al., 2017; D'Agua et al., 2015; Davydenko et al., 2014; Gendek et al., 2018). Briquettes incorporate non-toxic and nonpolluting recycled materials and could be a form of environmental clean-up involving collection of waste materials. Furthermore, they offer a more appealing alternative to the felling of trees. Figure 1 illustrates the 
proportion of academic studies conducted on the use of agricultural, forestry, textile, and food sector residues in the manufacture of briquettes. Between 2015 to 2020, most studies have focused on the manufacture of briquettes from food waste, followed using agricultural residue, forestry residue and, finally, textile waste.

\subsection{Pellets}

Pellets are a similar but smaller-scale equivalent to briquettes, ranging from 6 to 7.25 $\mathrm{mm}$ in diameter and between 10 and $36 \mathrm{~mm}$ in length. They have an average moisture content of between 6 and 10\%, an ash content of below 3\%, a bulk density greater than $639 \mathrm{~kg} / \mathrm{m}^{3}$, and a calorific value of around 4.7 kWh/kg (16.9 MJ/kg) (Arulprakasajothi et al., 2020; Lunguleasa et al., 2019; Ozturk et al., 2019). Effectively, they are a granulated form of biomass (Pinheiro et al., 2016; Spirchez et al., 2018).

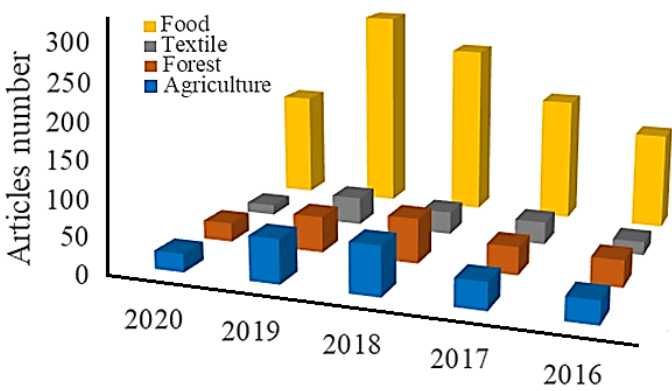

Figure 2. Published works concerning use of agricultural, forestry, textile, and food sector waste in the manufacture of pellets. (The research was searched in the SCOPUS database and Web of Science, with the keywords: pellets; briquette; waste; biomass).

Like briquettes, pellets are manufactured by the compaction or compression of waste materials (Durango et al., 2019; Marrugo et al., 2019). The main raw materials are residue from sawmills and the furniture industry, including rejected planks, sawdust, wood chips, offcuts, and dry shavings.
These are compacted in a high-pressure mill, where the lignin content of the wood acts as a binder. Other forms of biomass, such as coal dust, can also be incorporated (Hidalgo et al., 2018). Wood pellets offer an attractive alternative to fuels such as coal, chopped wood, oil and other fossil fuel derivatives. They are also relatively cheap and easy to store, provide uniform combustion, have a low moisture content, and release smaller amounts of contaminant gases (Forero-Núñez et al., 2014). In particular, pellets constitute a more environmentally friendly option given their lower $\mathrm{CO}_{2}$ emissions than solid or chipped wood (Soto and Núñez, 2008). Figure 2 illustrates the proportion of academic studies conducted on the use of agricultural, forestry, textile, and food sector residues in the manufacture of pellets. Between 2015 to 2020, most studies have focused on the manufacture of pellets from food waste, followed using agricultural residue, forestry residue and, finally, textile waste.

\section{Waste from different productive sec- tors in the manufacture of briquettes \\ 3.1 Agricultural sector}

Production of first and second generation solid, liquid and gas biofuels (Boutesteijn et al., 2017) from biomass is achieved by the processing of primary sources and agricultural and industrial waste from forestry, farming and livestock activities (GutierrezMacias et al., 2015), and from bushy and arboreal roundwood plantations. The process helps to improve agricultural sustainability and to protect natural resources such as water and soils. Production of biofuels using primary waste from agriculture and industry, roundwood plantations, and forestry, farming and livestock activities, particularly on underexploited soils, constitutes a viable option today (Weiss and Glasner, 2018).

Table 1

Agricultural waste as raw materials for the manufacture of biomass briquettes

\begin{tabular}{|c|c|c|}
\hline Waste/residue type & $\begin{array}{l}\text { Calorific value } \\
\text { (MJ/kg) }\end{array}$ & References \\
\hline $\begin{array}{l}\text { Sugarcane skin, } \\
\text { Bamboo fiber }\end{array}$ & $\begin{array}{l}\text { SCS: } 17.23 \\
\text { BF: } 16.92\end{array}$ & (Brunerova et al., 2018) \\
\hline Hemp and sunflower fiber & $16.6-17.4$ & \multirow{3}{*}{$\begin{array}{l}\text { (Alaru et al., 2011) } \\
\text { (Muñoz-Muñoz et al., 2014) } \\
\text { (de Oliveira et al., 2014) } \\
\text { (Bautista-Ramírez et al., } \\
\text { 2019) }\end{array}$} \\
\hline $\begin{array}{l}\text { Sugarcane bagasse, sisal dust, cassava bran } \\
\text { Semi-dried banana leaves }\end{array}$ & $\begin{array}{l}15 \\
17.7\end{array}$ & \\
\hline Maize & 15.8 & \\
\hline $\begin{array}{l}\text { Sugarcane bagasse; coffee, rice, and soybean husk; peanut and } \\
\text { caster seed shell; wheat and rice straw; maize, sunflower, jute, } \\
\text { mustard, and cotton stalks; coir pith; tobacco wastes }\end{array}$ & $13.4-20.7$ & (Patil, 2019) \\
\hline Moringa oleifera biomass & $15.87-23.31$ & (Pereira et al., 2018) \\
\hline Piñon (Araucaria angustifolia) residue & $17.6-18.6$ & (Jacinto et al., 2016) \\
\hline Rice husk and bran & 16.08 & (Yank et al., 2016) \\
\hline Vine shoots, grape skins, stems, and seeds & $18.4-20.6$ & (Rojas et al., 2018a) \\
\hline
\end{tabular}


The climatic conditions of certain countries provide a favorable environment in which to adapt various annual and perennial plant species to the production of biomass which can then be transformed into bioenergy (Benie et al., 2005). However, the primary obstacle to the production of these biofuels is the relative scarcity of suitable agricultural land (Gao et al., 2019). The most abundant sources of agricultural biomass for the production of roundwood-, pellet-, briquette- and wood chip-based biofuels are residues from forestry activities, waste from the furniture industry, and the products of roundwood plantations (Clavijo et al., 2020). Other important sources are cereals (maize, wheat, oats, barley), tubers (potato, beet, fodder turnip), and forestry biomass and its derivatives (lignocellulosic residues from harvesting and agro-industry). Each of these can be converted into liquid biofuels such as ethanol, methanol, and bio-oil. Oils from oilseeds (safflower, linseed, sunflower, rape, castor, jojoba, jatropha), algae and other species, along with recycled vegetable oils and animal fats can be used to produce liquid biofuel such as biodiesel. Livestock manure; slaughterhouse waste; agricultural, agro-industrial and wholesale market residues; viticulture and winemaking residues; whey; and lignocellulosic residues can all be used to produce gas biofuels such as biogas. Nut shells and cassava flour have been incorporated as binders in the manufacture of briquettes (Chungcharoen and Srisang, 2020). The agricultural sector therefore plays a vital role as a generator of biomass suitable for conversion into biofuels and bioenergy (Javed et al., 2019; Samadi et al., 2020). Several agricultural sector waste types and their calorific values are presented in Table 1.

\subsection{Forestry sector}

Forestry activities generate large amounts of organic waste or biomass, which can be used for the production of biofuels that are less polluting than fossil fuel alternatives
(Ayala-Mendivil and Sandoval, 2018). Biomass in the form of residues produced by tree plantations, pulp plants and sawmills (Table 2) can be used for the manufacture of briquettes or pellets. For example, sugarcane residue has been combined with pine sawdust and red angelim (Dinizia excelsa) to make briquettes (Fernandez et al., 2017). Forestry residues can be categorized as timber-yielding and non-timber-yielding. The first category includes usable woody materials (e.g., crown, branches, foliage, stumps, shavings, sawdust, offcuts, bark, sawn timber), while the second consists of the non-woody vegetation of a forest ecosystem (e.g., seeds, fibers, rubbers, waxes, rhizomes, leaves, stalks and stems, lichens, mosses, fungi, resins and soils) (AyalaMendivil and Sandoval, 2018).

Natural forest biomass refers to the organic material within a forest ecosystem, while dry residual biomass constitutes material generated by forestry activities and the timber industry. Wet residual biomass refers to biodegradable waste, including urban and industrial wastewater and livestock waste, primarily manure. Finally come the energy crops, which are grown solely as biomass for conversion into biofuel. These include roundwood plantations (de Bikuna et al., 2020; Jasiunas et al., 2020; Stolarski et al., 2019; Yang et al., 2020).

Conversion of forest residues into biomass has several advantages. In terms of energy generation, it has the potential to lower costs and yield a reduction in fossil fuel dependence. Environmentally, it means increased waste recycling, a reduction in the risk of forest fires, lower greenhouse gas emissions, and improvements to the quality of forest biomass. In socio-economic terms, biomass processing directly and indirectly creates jobs, provides the population with cheaper energy compared with that generated from fossil fuels, and results in lower rural to urban migration (Jackson et al., 2018; Ko et al., 2019; Liu and Rajagopal, 2019; Purohit and Chaturvedi, 2018).

Table 2

Forest residues as raw materials for the manufacture of biomass briquettes

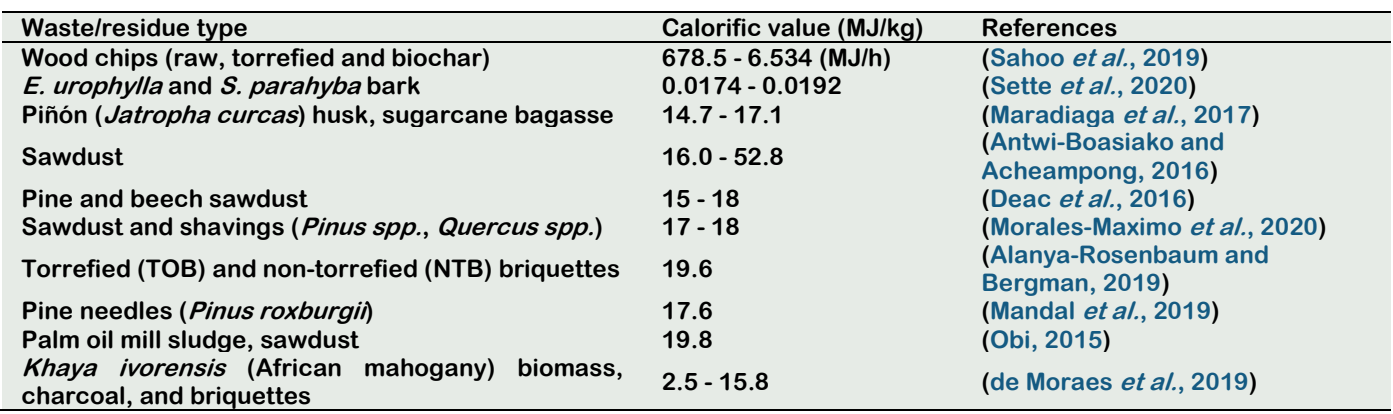


Table 3

Textile waste as raw materials to produce biomass briquettes

\begin{tabular}{lll}
\hline Waste/residue type & $\begin{array}{l}\text { Calorific value } \\
\text { (MJ/kg) }\end{array}$ & References \\
\hline Biological sludge, cotton and other microfibres & $16.3-23.5$ & (Avelar et al., 2016) \\
Wood pulp, paper, and textile sludge & $8.85-10.55$ & (Chiou and Wu, 2014) \\
Metallurgical coke, pregelatinized starch, polyvinyl alcohol & 28.4 & (Rajput and Thorat, 2020) \\
Cotton, polyester & $15.5-16.8$ & (Nunes et al., 2018) \\
Polyester fibers, cotton, starch, lumps, and old rags & $14.9-20.9$ & (Suvunnapob et al., 2015) \\
Cotton fabric and textiles & $15.70-16.26$ & (Yasin et al., 2020) \\
Textile dyeing sludge and cattle manure & $4.11-15.86$ & (Zhang et al., 2020) \\
Household waste, canary grass, plastic, and textile fraction & 18 & (Hedman et al., 2007) \\
Textile industry wastewater, rice straw & 10 & (Moliner et al., 2018) \\
Rubber elastomers, carbon black, metal, textile, zinc oxide, & $<0.000198$ & (Landi et al., 2018) \\
others & & \\
\hline
\end{tabular}

\subsection{Textile sector}

Globally, the textile industry generates sales of at least US\$ 2.5 trillion and provides at least 75 million jobs; however, despite high demand, profit has declined due to price differentiation (Yaghin, 2020). The industry is also responsible for $10 \%$ of carbon emissions globally, produces around $20 \%$ of the world's wastewater, and consumes vast amounts of energy. Less than $1 \%$ of the material produced by the textile industry is recycled, resulting in a loss of at least US\$ 100 billion in raw materials each year. Around $85 \%$ of textiles are sent to landfill or incinerated, and $73 \%$ of clothing destined for reuse is lost before it can be processed. Greater recycling and reuse of textile waste would contribute considerably to addressing the environmental issue (Calvo and Williams, 2019; Lucato et al., 2017; Shevchenko et al., 2019).

The textile industry is one of the most polluting and consumes large amounts of resources, including raw materials (both natural and synthetic), water, transportation, and treatment of waste, primarily in the form of primary and biological sludge from wastewater treatment. For example, India's textile and clothing industry exported $12.4 \%$ of the global total in 2017, generating textile

\subsection{Food sector}

A review of the relevant literature reveals considerable variation in definitions and classifications of food waste. One debate concern whether food waste should refer exclusively to the edible parts of food or to inedible parts as well. Another questions whether food waste should be limited to materials destined for human consumption or extended to waste generated along the supply chain, given the multiple potential sources of biomass provided by the food sector. The most widely accepted approach is to consider those edible foodstuffs discarded early in the supply chain; that is, during production, post-harvest, and industrial processing. Also included are those edible waste of which only around $8 \%$ was recycled (cotton and artificial fabrics and threads, woolen and silk fabric, makeup and clothing) (Jafari, 2019; Kim, 2019; Navone et al., 2020). Furthermore, textile sludge varies in composition, but tends to contain high levels of organic material, nitrogen, phosphorus and micronutrients, as well as dyes and heavy metals (Avelar et al., 2016; Yuvaraj et al., 2020). Disposal of textile waste represents a high cost to companies, and repurposing of the various residue types by transforming them into valuable biofuel subproducts (Table 3 ) constitutes an attractive option. An example of this is the manufacture of briquettes from solid textile waste (Avelar et al., 2016), which would go some way towards mitigating environmental damage (Avelar et al., 2016; Nunes et al., 2018; Piribauer and Bartl, 2019; Turemen et al., 2019). Another means of classifying biomass from the textile sector is to differentiate between post-industrial waste (material left over from the processing and cutting of fabrics), pre-consumption waste (garments which do not reach the market due to defects or which are discarded by the manufacturer), and post-consumption waste (finished material that has reached the end of its usable life).

and inedible food parts that are removed from the supply chain, such as those destined for composting, anaerobic digestion (Gustavsson et al., 2011), or bioenergy. One example of the latter is the manufacture of briquettes using bean husk waste from coffee production, achieving an activation energy value of between $104.90 \mathrm{~kJ} / \mathrm{mol}$ and $345.2 \mathrm{~kJ} / \mathrm{mol}$ (Setter et al., 2020). Many authors define food waste as goods produced for human consumption but which, for various reasons, are discarded or used for other unrelated purposes (Alexander et al., 2017; Buzby and Hyman, 2012; Griffin et al., 2009). Fresh vegetables, for example, are considered food waste (Table 4) if they reach maturity and are not harvested for economic reasons, as a result of damage caused by 
animals, or due to climatic factors, poor seed quality, excess production, insufficient growth, or unappealing appearance (Ayerst et al., 2020; Cattaneo et al., 2020; Narciso, 2020; Newman and Tarp, 2019). They are also considered food waste if they are harvested but are subsequently discarded as unsuitable for human consumption due to chemical contamination, excessive or insufficient pesticide use, infestations, infections, transport and storage issues, or noncompliance with quality or aesthetic standards (Frison and Clément, 2020). Animal products, including those resulting from human food production, are considered food waste if they are destined for energy valorization, anaerobic digestion, or composting. It is during the industrial processing stage that the largest quantity of food waste is produced, including that resulting from production errors and/or changes; excess production; non-compliance with standards; poor management, handling, storage or transportation (within facilities); and inedible materials left over from the process. Globally, between 20 and $40 \%$ of food waste is generated during the manufacturing stage (Garcia-García et al., 2017; Masud et al., 2020; Qi et al., 2020; Teigiserova et al., 2020; Westerholm et al., 2020).

\section{Perspectives on waste and chal- lenges for the future}

According to estimates by the International Monetary Fund, global economic growth will rise from $2.9 \%$ in 2019 to $3.3 \%$ in 2020 , driven by manufacturing and international trade. The global urban population has grown rapidly since 1950 , increasing from 746 million to 3.9 mil millions in 2014 (Nations-United, 2014) and to 7.7 mil millions 2019 (Nations-United, 2019). This growth and development has had negative impacts on climate change, the risk of international conflict over access to strategic resources, and the growing threat of epidemics and pandemics (Acikgoz and Gunay, 2020; Lomborg, 2020; Sarkodie et al., 2020a; Sarkodie et al., 2020b).
Global waste generation is expected to grow from 2 mil millions tons to 3.4 mil millions tons by 2050 (Kaza et al., 2018). According to the World Bank, the East Asia and Pacific regions generate $23 \%$ of the world's waste, while $34 \%$ is created by high-income countries. This waste consists of plastic (12\%), green foods $(44 \%)$, glass $(5 \%)$, metal $(4 \%)$, paper and card $(17 \%)$, rubber and leather $(2 \%)$, wood $(2 \%)$, and other materials $(14 \%)$. According to the United Nations, treatment and disposal of waste is achieved by composting $(5.5 \%)$, incineration $(11.1 \%)$, controlled landfill (3.7\%), unspecified landfill

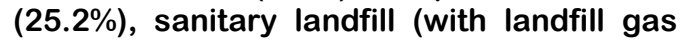
collection, $7.7 \%)$, open dump $(33 \%)$, recycling $(13.5 \%)$, and other solutions $(0.3 \%)$. These projections and figures are a clear illustration of the startling accumulation of waste around the world and the short-term impact that this is having on the environment. Development and implementation of improved farming practices could drive a reduction of at least $30 \%$ in waste generation globally, including through the conversion of these residues into new energy products that offer a valuable ecological alternative to conventional fossil fuels (Moustakas et al., 2020; Shariat Panahi et al., 2020; Shirzad et al., 2019).

Furthermore, there is a need for the diverse legislation of emerging and developing countries to be brought into line with more demanding waste treatment standards, such as those of Europe, North America and Japan (Mutz et al., 2017). Many countries around the world have seen an opportunity to develop strategies based on the technological and economic model of the circular economy (Momete, 2020); that is, to reduce (reduce the volume of waste generated by, for example, the agricultural, forestry, textile and food industries, as well as the cost of collection and treatment of waste), to reuse (cleaning and repair of a discarded product so that it can be reused), and to recycle (collection and transformation of waste into secondary raw materials) (Dau et al., 2019; Rosa et al., 2020).

Table 4

Food waste as raw materials for the manufacture of biomass briquettes

\begin{tabular}{lll}
\hline Waste/residue type & Calorific value (MJ/kg) & References \\
\hline Charcoal, wild cassava, bioethanol & $17.7-19.7$ & (Gesase et al., 2020) \\
Recovered wood, food waste & $19.5-21.3$ & (Myrin et al., 2014) \\
Molasses as a binder & $23.54-29.21$ & (Wang et al., 2019) \\
Food waste & $0003-0.009$ & (Elkhalifa et al., 2019) \\
Artichoke stalks, wheat straw & $15.6-17.71$ & (Titei et al., 2019) \\
Food processing sludge & $18.59-25.70$ & (Chiou et al., 2015) \\
Jackfruit peel waste & $20.1-22.6$ & (Pratiwi et al., 2019) \\
Food waste, molasses & $25.2-32.3$ & (Zhai et al., 2018) \\
Olive oil waste & 31.8 & (Arvanitoyannis et al., 2007) \\
Coconut fiber, rice husk, mineral coal & $0.0158-0.0239$ & (Hoyos et al., 2019) \\
\hline
\end{tabular}


The success of the circular economy model depends on appropriate management of waste. This includes promotion of product repair and reuse, increases in efficiency in terms of energy and resource consumption, increases in the recycled content of new products, boosting of high-quality remanufacturing and recycling, reductions in carbon footprint and in the use of water and other crucial materials, the elimination of single-use products and of planned obsolescence, a move towards business models based on products as services, promoting digital transformation and traceability of products and materials, and promoting efficient and environmentally sensitive economic growth (Çetinay et al., 2020; Cramer, 2020; Jabbour et al., 2020; Kokkinos et al., 2020).

\section{Conclusions}

Humanity is currently facing serious environmental challenges. Advancements in technology, population growth, urbanization and increased energy consumption are producing vast quantities of waste, and the use of environmentally harmful processes to meet energy demands are driving climate change and threatening the world's ecosystems. The need to formulate and implement new programs of waste repurposing, sustainability and renewable energy production is now more urgent than ever. Significant advances have been made in these areas in recent years, but far more is required if we are to address the environmental challenges of our time in any meaningful way. Future research should address Industry 4.0 and the green and circular economies, placing the focus on utilization of agricultural, forestry, textile and food industry waste, the development of new waste-based businesses, the generation of energy by alternative means, and the global alignment of production, recycling and waste repurposing policies.

\section{Acknowledgements}

The authors thank the support of the internal project of the University of Los Lagos INTAPLOS - 2016.

\section{ORCID}

T. Espinoza-Tellez (D) https://orcid.org/0000-0003-1491-1051

J. Bastías $\mathbb{D}$ https://orcid.org/0000-0003-3387-6917

R. Quevedo-León (1) https://orcid.org/0000-0001-8132-838X

E. Valencia-Aguilar (D) https://orcid.org/0000-0001-5748-9415

H. Aburto (1) https://orcid.org/0000-0001-5928-3605

D. Díaz-Guineo $\mathbb{D}$ https://orcid.org/0000-0003-2216-931X

M. Ibarra-Garnica (D) https://orcid.org/0000-0002-4968-1973

O. Díaz-Carrasco $\mathbb{D}$ https://orcid.org/0000-0002-0937-9825

\section{References}

Acikgoz, O.; Gunay, A. 2020. The early impact of the Covid-19 pandemic on the global and Turkish economy. Turkish Journal of Medical Sciences 50: 520-526.
Ahmad, T.; Belwal, T.; Li, L.; et al. 2020. Utilization of wastewater from edible oil industry, turning waste into valuable products: A review. Trends in Food Science \& Technology 99: 21-33.

Alanya-Rosenbaum, S.; Bergman, R.D. 2019. Life-cycle impact and exergy based resource use assessment of torrefied and non-torrefied briquette use for heat and electricity generation. Journal of Cleaner Production 233: 918-931.

Alarenan, S.; Gasim, A.A.; Hunt, L.C. 2020. Modelling industrial energy demand in Saudi Arabia. Energy Economics 104554 85: 1-10.

Alaru, M.; Kukk, L.; Olt, J.; et al. 2011. Lignin content and briquette quality of different fibre hemp plant types and energy sunflower. Field Crops Research 124: 332-339.

Alexander, P.; Brown, C.; Arneth, A.; et al. 2017. Losses, inefficiencies and waste in the global food system. Agricultural Systems 153: 190-200.

Amarasekara, A.; Tanzim, F.S.; Asmatulu, E. 2017. Briquetting and carbonization of naturally grown algae biomass for low-cost fuel and activated carbon production. Fuel 208: 612-617.

Anggono, W.; Sutrisno; Suprianto, F.D.; et al. 2018. Biomass Briquette Investigation from Pterocarpus Indicus Twigs Waste as an Alternative Renewable Energy. International Journal of Renewable Energy Research 8: 1393-1400.

Antwi-Boasiako, C.; Acheampong, B. 2016. Strength properties and calorific values of sawdustbriquettes as wood-residue energy generation source from tropical hardwoods of different densities. Biomass and Bioenergy 85: 144-152.

Aransiola, E.; Oyewusi, T.; Osunbitan, J.; et al. 2019. Effect of binder type, binder concentration and compacting pressure on some physical properties of carbonized corncob briquette. Energy Reports 5: 909-918.

Arias, T.; López, L. 2015. Propuesta tecnológica para el aprovechamiento energético del bagazo de cebada malteada de la cervecería Hatuey. Revista Científica de Tecnología Química 35: 256-270.

Arulprakasajothi, M.; Beemkumar, N.; Parthipan, J.; et al. 2020. Investigating the Physio-chemical Properties of Densified Biomass Pellet Fuels from Fruit and Vegetable Market Waste. Arabian Journal for Science and Engineering 45: 563-574

Arvanitoyannis, I.S.; Kassaveti, A.; Stefanatos, S. 2007. Current and potential uses of thermally treated olive oil waste. International Journal of Food Science and Technology 42: 852-867.

Avelar, N.; Rezende, A.; Carneiro, A.; et al. 2016. Evaluation of briquettes made from textile industry solid waste. Renewable Energy 91: 417-424.

Ayala-Mendivil, N.; Sandoval, G. 2018. Bioenergy from forest and wood residues. Madera $Y$ Bosques 24: 1 14.

Ayerst, S.; Brandt, L.; Restuccia, D. 2020. Market constraints, misallocation, and productivity in Vietnam agriculture. Food Policy 101840: 1-16.

Balasubramani, P.; Anbumalar, V.; Nagarajan, M.; et al. 2016. Biomass briquette manufacturing system model for environment. Journal of Alloys and Compounds 686: 859-865.

Bautista-Ramírez, E.; Salinas-Moreno, Y.; SantracruzVarela, A.; et al. 2019. Características físicas y químicas de la raza de maíz Palomero Toluqueño. Revista Mexicana de Ciencias Agrícolas 10: 441-446.

Benie, G.B.; Kabore, S.S.; Goita, K.; et al. 2005. Remote sensing-based spatio-temporal modeling to predict biomass in Sahelian grazing ecosystem. Ecological Modelling 184: 341-354.

Berastegui, C.; Ortega, J.; Mendoza, J.; et al. 2017. Elaboración de biocombustibles sólidos densificados a partir de tusa de maíz, bioaglomerante de yuca y carbón mineral del departamento de Córdoba. Ingeniare. Revista Chilena de Ingeniería 25: 643-653.

Boutesteijn, C.; Drabik, D.; Venus, T.J. 2017. The interaction between EU biofuel policy and first- and 
second-generation biodiesel production. Industrial Crops and Products 106: 124-129.

Brunerova, A.; Roubik, H.; Brozek, M. 2018. Bamboo Fiber and Sugarcane Skin as a Bio-Briquette Fuel. Energies 11: 1-20.

Busov, V.B. 2018. Manipulation of Growth and Architectural Characteristics in Trees for Increased Woody Biomass Production. Frontiers in Plant Science 9: 1-8.

Buzby, J. C.; Hyman, J. 2012. Total and per capita value of food loss in the United States. Food Policy 37: 561 570 .

Calvo, S.; Williams, G. 2019. Reutilización de residuos textiles: Industria, contexto, situación en Chile y legislación comparada. In "Biblioteca del Congreso Nacional de Chile ". N SUP: 0932223 1-7.

Campuzano-Duque, L.; Ríos, L.; Cardeño-López, F. 2016. Caracterización composicional del fruto de 15 variedades de Jatropha curcas L. en el departamento del Tolima, Colombia. Corpoica Cienc Tecnol Agropecuaria 17: 379-390.

Cattaneo, A.; Federighi, G.; Vaz, S. 2020. El impacto ambiental de reducir la pérdida y el desperdicio de alimentos: una evaluación crítica. Food policy 101890: 1-16.

Çetinay, H.; Donati, F.; Heijungs, R.; et al. 2020. Efficient computation of environmentally extended inputoutput scenario and circular economy modeling. Journal of Industrial Ecology 13013: 1-10.

Chiou, I.; Wu, I. 2014. Evaluating the manufacturability and combustion behaviors of sludge-derived fuel briquettes. Waste Management 34: 1847-1852.

Chiou, I.J.; Chen, C.H.; Liu, W.L.; et al. 2015. Fuel briquettes from food-processing sludge. Environmental Progress \& Sustainable Energy 34: 1790-1795

Chungcharoen, T.; Srisang, N. 2020. Preparation and characterization of fuel briquettes made from dual agricultural waste: Cashew nut shells and areca nuts. Journal of Cleaner Production 256: 1-143.

Clavijo, L.; Zlatanovic, S.; Braun, G.; et al. 2020. Eucalyptus Kraft Lignin as an Additive Strongly Enhances the Mechanical Resistance of Tree-Leaf Pellets. Processes 8: 1-9.

Cramer, J.M. 2020. Practice-based model for implementing circular economy: The case of the Amsterdam Metropolitan Area. Journal of Cleaner Production 255: 1-9.

D’Agua, J.; Pereira, R.; Marinho, F. 2015. Preparación y Caracterización Física del Biocombustible Sólido del Lirio Acuático (Eichhornia crassipes). Información Tecnológica 26: 53-62.

Dau, G.; Scavarda, A.; Scavarda, L.F.; et al. 2019. The Healthcare Sustainable Supply Chain 4.0: The Circular Economy Transition Conceptual Framework with the Corporate Social Responsibility Mirror. Sustainability 11: 1-19.

Davydenko, A.; Mostafaee, S.; Karasev, A.; et al. 2014. Caracterización de briquetas de escoria espumante en el horno de arco eléctrico durante la producción de acero inoxidable. Steel research international 86: 137-145.

de Bikuna, K.S.; Garcia, R.; Dias, A.C.; et al. 2020. Global warming implications from increased forest biomass utilization for bioenergy in a supply-constrained context. Journal of Environmental Management 263: 1-10.

de Moraes, M.D.A.; da Silva, M.F.; Barbosa, P.V.G.; et al. 2019. Characterization of Khaya ivorensis (A. Chev) biomass, charcoal and briquettes. Scientia Forestalis 47: 34-44.

de Oliveira, B.; Souzab, O.; Marangonib, C.; et al. 2014 Production and Characterization of Fuel Briquettes from Banana Leaves Waste Chemical Engineering Transactions 37: 439-444

Deac, T.; Fechete-Tutunaru, L.; Gaspar, F. 2016. Environmental Impact of Sawdust Briquettes Use an Experimental Approach. Energy Procedia 85: 178183.
Durango, E.; Berastegui, C.; Mendoza, J. 2019. Efecto de la adición de aglomerantes en las propiedades mecánicas de los pellets de biomasa. Ingeniare. Revista Chilena de Ingeniería 27: 83-88.

Elkhalifa, S.; Al-Ansari, T.; Mackey, H.R.; et al. 2019. Food waste to biochars through pyrolysis. Resources Conservation and Recycling 144: 310-320.

Fernandez, B.O.; Goncalves, B.F.; Pereira, A.C.C.; et al. 2017. Mechanical and Energetic Characteristics of Briquettes Produced from Different Types of Biomass. Revista Virtual De Quimica 9: 29-38.

Forero-Núñez, C.; Camargo-Vargas, G.; Sierra-Vargas, F. 2014. Modelos de compresión aplicados al proceso de densificación de combustibles sólidos binarios carbón-madera. Iteckne 11: 196-203.

Frison, E.; Clément, C. 2020. El potencial de los sistemas agroecológicos diversificados para ofrecer resultados saludables: establecer el vínculo entre la agricultura, los sistemas alimentarios y la salud. Food policy 101851: 1-8.

Gangil, S. 2015. Superiority of intrinsic biopolymeric constituents in briquettes of lignocellulosic crop residues over wood: A TG-diagnosis. Renewable Energy 76: 478-483.

Gao, J.Q.; Yang, X.G.; Zheng, B.Y.; et al. 2019. Effects of climate change on the extension of the potential double cropping region and and crop water requirements in Northern China. Agricultural and Forest Meteorology 268: 146-155.

García-García, G.; Woolley, E.; Rahimifard, S. 2017. Optimizando la Gestión de Residuos Industriales de Alimentos. Procedia Manufacturing 8: 432-439

Gendek, A.; Aniszewska, M.; Malaták, J.; et al. 2018. Evaluation of selected physical and mechanical properties of briquettes produced from cones of three coniferous tree species. Biomass and Bioenergy 117: 173-179.

Gesase, L.; King'ondu, C.; Jande, Y. 2020. Briquetas de polvo de carbón de leña envasadas e infundidas con bioetanol Manihot glaziovii: una nueva ruta para abordar los problemas de sostenibilidad, ignición y seguridad alimentaria en la producción de briquetas. Investigación bioenergética 13: 378-386.

Go, A.; Conag, A.; Igdon, R.; et al. 2019. Potentials of agricultural and agro-industrial crop residues for thedisplacement of fossil fuels: A Philippine contex. Energy Strategy Reviews 23: 100-113.

Griffin, M.; Sobal, J.; Lyson, T. A. 2009. An analysis of a community food waste stream. Agriculture and Human Values 26: 67-81.

Guo, X.L.; Zhang, T.J. 2020. Utilization of municipal solid waste incineration fly ash to produce autoclaved and modified wall blocks. Journal of Cleaner Production 252: 1-13.

Gustavsson, J.; Cederberg, C.; Sonesson, U.; et al. 2011. Global Food Losses and Food Waste. In "Food and agriculture organization of the united nations", Vol. ISBN 978-92-5-107205-9. 1-37.

Gutierrez-Macias, P.; Montanez-Barragan, B.; BarraganHuerta, B.E. 2015. A review of agro-food waste transformation into feedstock for use in fermentation. Fresenius Environmental Bulletin 24: 3703-3716.

Hansted, A.; Nakashima, G.; Martins, M.; et al. 2016. Caracterização Físico-Química da Biomassa de Leucaena leucocephala para Produção de Combustível Sólido Rev. Virtual Quim. 20: 1-12.

Hedman, B.; Burvall, J.; Nilsson, C.; et al. 2007. PCDD/F in source-sorted waste fractions and emissions from their co-combustion with reed canary-grass. Waste Management 27: 1580-1592.

Hernandez, J.J.; Ballesteros, R.; Barba, J.; et al. 2015. Effect of the Addition of Biomass Gasification Gas on the PM Emission of a Diesel Engine. Sae International Journal of Engines 8: 14-19.

Hidalgo, D.; Antolín, G.; Alvarellos, I.; et al. 2018. Producción de biometano para combustible de transporte a partir de residuos de biomasa. In "Biometrans". Cyted, 1-148. 
Hoyos, C.; González, Y.; Mendoza, J. 2019. Elaboración de biocombustibles sólidos densificados a partir de la mezcla de dos biomasas residuales, un aglomerante a base de yuca y carbón mineral, propios del departamento de Córdoba. Ingeniare. Revista Chilena de Ingeniería 27: 454-464.

Jabbour, C.J.C.; Seuring, S.; Jabbour, A.; et al. 2020. Stakeholders, innovative business models for the circular economy and sustainable performance of firms in an emerging economy facing institutional voids. Journal of Environmental Management 264: 1 13.

Jacinto, R.C.; Brand, M.A.; Rios, P.D.; et al. 2016. Analysis of the energy quality pinion fails to produce briquettes. Scientia Forestalis 44: 821-829.

Jackson, R.W.; Neto, A.B.F.; Erfanian, E. 2018. Woody biomass Processing: Potential economic impacts on rural regions. Energy Policy 115: 66-77.

Jafari, H. 2019. Sustainable development by reusing of recyclables in a textile industry including two collectors and three firms: A game-theoretic approach for pricing decisions. Journal of Cleaner Production 229: 598-610.

Jain, M. S.; Kalamdhad, A. S. 2020. Soil revitalization via waste utilization: Compost effects on soil organic properties, nutritional, sorption and physical properties. Environmental Technology Innovation 18: 1-38.

Jalgaonkar, K.; Mahawar, M.K.; Bibwe, B.; et al. 2020 Postharvest Profile, Processing and Waste Utilization of Dragon Fruit (Hylocereus Spp.): A Review. Food Reviews International 101080: 1-27.

Jasiunas, L.; Skvorcinskiene, R.; Miknius, L. 2020. Wet and Coarse: The Robustness of Two-Stage Crude Glycerol Mediated Solvothermal Liquefaction of Residual Biomass. Waste and Biomass Valorization 11: 2171-2181.

Javed, U.; Ansari, A.; Aman, A.; et al. 2019. Fermentation and saccharification of agro-industrial wastes: A cost-effective approach for dual use of plant biomass wastes for xylose production. Biocatalysis and Agricultural Biotechnology 21: 1-6.

Ji, C.; Cheng, K.; Nayak, D.; et al. 2018. Environmental and economic assessment of crop residue competitiveutilization for biochar, briquette fuel and combined heat and powergeneration. Journal of Cleaner Production 192: 916-923.

Karner, K.; Dissauer, C.; Enigl, M.; et al. 2017. Environmental trade-offs between residential oilfired and wood pellet heating systems: Forecast scenarios for Austria until 2030. Renewable \& Sustainable Energy Reviews 80: 868-879.

Kayo, C.; Ojimi, R.; Iwaoka, M.; et al. 2016. Greenhouse Gas Emission Reductions in a District Heating and Cooling System by Using Woody Biomass A study in Shiwa, Iwate Prefecture. Mokuzai Gakkaishi 62: 172181.

Kaza, S.; Yao, L.; Bhada-Tata, P.; et al. 2018. What a Waste 2.0: una instantánea global de la gestión de residuos sólidos para 2050 Banco mundial 2174: 1 38.

Kim, M. 2019. Export Competitiveness of India's Textiles and Clothing Sector in the United States. Economies 7: 1-17.

Ko, S.; Lautala, P.; Fan, J.Q.; et al. 2019. Economic, social, and environmental cost optimization of biomass transportation: a regional model for transportation analysis in plant location process. Biofuels Bioproducts \& Biorefining-Biofpr 13: 582 598.

Kokkinos, K.; Karayannis, V.; Moustakas, K. 2020. Circular bio-economy via energy transition supported by Fuzzy Cognitive Map modeling towards sustainable low-carbon environment. Science of the Total Environment 721: 1-54

Landi, D.; Gigli, S.; Germani, M.; et al. 2018. Investigating the feasibility of a reuse scenario for textile fibres recovered from end-of-life tyres. Waste Management 75: 187-204.
Liu, B.; Rajagopal, D. 2019. Life-cycle energy and climate benefits of energy recovery from wastes and biomass residues in the United States. Nature Energy 4: 700-708.

Lomborg, B. 2020. Welfare in the 21st century: Increasing development, reducing inequality, the impact of climate change, and the cost of climate policies. Technological Forecasting and Social Change 156: 1-35.

Lucato, W.C.; Costa, E.M.; Neto, G.C.D. 2017. The environmental performance of SMEs in the Brazilian textile industry and the relationship with their financial performance. Journal of Environmental Management 203: 550-556.

Ludevese-Pascual, G.; Dela Pena, M.; Tornalejo, J. 2016. Biomass production, proximate composition and fatty acid profile of the local marine thraustochytrid isolate, Schizochytrium sp LEY7 using low-cost substrates at optimum culture conditions. Aquaculture Research 47: 318-328.

Lunguleasa, A.; Ayrilmis, N.; Spirchez, C.; et al. 2019. Increasing the Calorific Properties of Sawdust Waste from Pellets by Torrefaction. Bioresources 14: 78217839.

Makela, M.; Fullana, A.; Yoshikawa, K. 2016. Ash behavior during hydrothermal treatment for solid fuel applications. Part 1: Overview of different feedstock. Energy Conversion and Management 121: 402-408.

Mandal, S.; Kumar, G.V. P.; Bhattacharya, T.K.; et al. 2019. Briquetting of Pine Needles (Pinus roxburgii) and Their Physical, Handling and Combustion Properties. Waste and Biomass Valorization 10: 2415-2424.

Manzoor, A.; Qazi, J.I.; ul Haq, I.; et al. 2017. Significantly enhanced biomass production of a novel biotherapeutic strain Lactobacillus plantarum (AS-14) by developing low cost media cultivation strategy. Journal of Biological Engineering 11: 1-10.

Maradiaga, W.; Evangelista, A.; Sette Jr, C.; et al. 2017. Producción de briquetas con residuos de cáscara de piñón manso (Jatropha curcas) y bagazo de caña de azúcar. Bosque 38: 527-533.

Marrugo, G.; Valdes, C.; Gomez, C.; et al. 2019. Pelletizing of Colombian agro-industrial biomasses with crude glycerol. Renewable Energy 134: 558568.

Martín, F. 2014. Pélets y briquetas. Ecología 2293: 54-62.

Martinez, J.F.G.; Gomez, L.M.T.; Guzman, M.F.S.; et al. 2020. Energy from biomass: alternative for the reduction of atmospheric emissions. Revista Digital Lampsakos 2145: 70-78.

Masud, M.; Ananno, A.; Ahmed, N.; et al. 2020. Investigación experimental de un novedoso sistema de secado de alimentos basado en calor residual. Journal of Food Engineering 281: 1-12.

Moliner, C.; Teruel-Juanes, R.; Primaz, C.T.; et al. 2018. Reduction of Nitrates in Waste Water through the Valorization of Rice Straw: Life libernitrate Project. Sustainability 10: 1-12.

Momete, D.C. 2020. A unified framework for assessing the readiness of European Union economies to migrate to a circular modelling. Science of the Total Environment 718: 1-9.

Morales-Maximo, M.; Ruiz-Garcia, V.M.; Lopez-Sosa, L.B.; et al. 2020. Exploitation of Wood Waste of Pinus spp for Briquette Production: A Case Study in the Community of San Francisco Pichataro, Michoacan, Mexico. Applied Sciences-Basel 10: 1-20.

Moustakas, K.; Loizidou, M.; Rehan, M.; et al. 2020. A review of recent developments in renewable and sustainable energy systems: Key challenges and future perspective. Renewable y Sustainable Energy Reviews 119: 1-6.

Muñoz-Muñoz, D.; Pantoja-Matta, A.; Cuatin-Guarin, M. 2014. Aprovechamiento de residuos agroindustriales como biocombustible y biorefinería. Rev.Bio.Agro 12: 10-19.

Murphy, F.; Sosa, A.; McDonnell, K.; et al. 2016. Life cycle assessment of biomass-to-energy systems in Ireland 
modelled with biomass supply chain optimisation based on greenhouse gas emission reduction. Energy 109: 1040-1055.

Musa, S. D.; Tang, Z. H.; Ibrahim, A. O., et al. 2018. China's energy status: A critical look at fossils and renewable options. Renewable \& Sustainable Energy Reviews 81: 2281-2290.

Mutz, D.; Hengevoss, D.; Hugi, C.; et al. 2017. Opciones para el aprovechamiento energético de residuos en la gestión de residuos sólidos urbanos (Gíz, ed.), pp. 1-60.

Myrin, E.S.; Persson, P.E.; Jansson, S. 2014. The influence of food waste on dioxin formation during incineration of refuse-derived fuels. Fuel 132: 165169.

Narciso, G. 2020. Crop prices and the individual decision to migrate. Food policy 91: 1-9.

Nations-United. 2014. World Urbanization Prospects. 352: 1-32.

Nations-United. 2019. How certain are the United Nations global population projections? 6: 1-4.

Navone, L.; Moffitt, K.; Hansen, K.A.; et al. 2020. Closing the textile loop: Enzymatic fibre separation and recycling of wool/polyester fabric blends. Waste Management 102: 149-160.

Newman, C.; Tarp, F. 2019. Choques y decisiones de inversión agrícola. Food Policy 101810: 1-9.

Nhuchhen, D.; Afzal, M. 2017. HHV Predicting Correlations for Torrefied Biomass Using Proximate and Ultimate Analyses. Bioengineering 4: 1-15.

Nino, A.; Arzola, N.; Araque, O. 2020. Experimental Study on the Mechanical Properties of Biomass Briquettes from a Mixture of Rice Husk and Pine Sawdust. Energies 13: 1-20.

Nunes, L.J.R.; Godina, R.; Matias, J.C.O.; et al. 2018. Economic and environmental benefits of using textile waste for the production of thermal energy. Journal of Cleaner Production 171: 1353-1360.

Obi, O.F. 2015. Evaluation of the effect of palm oil mill sludge on the properties of sawdust briquette. Renewable \& Sustainable Energy Reviews 52: 1749 1758.

Ozturk, H.H.; Ayhan, B.; Turgut, K. 2019. An assessment of the energetic properties of fuel pellets made by agricultural wastes. Scientific Papers-Series E-Land Reclamation Earth Observation Surveying Environmental Engineering 8: 9-16.

Pandey, G. 2019. Biomass based bio-electro fuel cells based on carbon electrodes: an alternative source of renewable energy. Sn Applied Sciences 1: 1-10.

Patil, G. 2019. The possibility study of briquetting agricultural wastes for alternative energy. Indonesian Journal of Forestry Research 6: 133-139.

Pereira, F.S.G.; de Sobral, A.D.; da Silva, A.; et al. 2018. Moringa oleifera: a promising agricultural crop and of social inclusion for Brazil and semi-arid regions for the production of energetic biomass (biodiesel and briquettes). Ocl-Oilseeds and Fats Crops and Lipids 25: 1-11.

Pinheiro, D.; Caraschi, J.; Ventorim, G.; et al. 2016. Trends and challenges of brazilian pellets industry originated from agroforestry. Cerne 22: 233-240.

Piribauer, B.; Bartl, A. 2019. Textile recycling processes, state of the art and current developments: A mini review. Waste Management Research 37: 112-119.

Pratiwi, Y.; Waluyo, J.; Widyawidura, W.; et al. 2019. Development of Jackfruit Peel Waste as Biomass Energy: Case Study for Traditional Food Center in Yogyakarta. International Journal of Renewable Energy Research 9: 2128-2135.

Purohit, P.; Chaturvedi, V. 2018. Biomass pellets for power generation in India: a techno-economic evaluation. Environmental Science and Pollution Research 25: 29614-29632.

Qi, D.; Lai, W.; Roe, B. 2020. El desperdicio de alimentos disminuyó más en los hogares rurales chinos con ganado. Food policy 101893: 1-15.

Rajput, S.P.; Thorat, B. N. 2020. Recovered polyvinyl alcohol as an alternative binder for the production of metallurgical quality coke breeze briquettes.
International Journal of Coal Preparation and Utilization 101080: 1-12.

Riuji, C.; Mtoro, H.; Sweeney, D.; et al. 2016. Char fuel production in developing countries - A review of urban biowaste carbonization. Renewable and Sustainable Energy Reviews 59: 1514-1530.

Robles, E.; Fernandez-Rodriguez, J.; Barbosa, A.M.; et al. 2018. Production of cellulose nanoparticles from blue agave waste treated with environmentally friendly processes. Carbohydrate Polymers 183: 294-302.

Rodriguez, W.; Evangelista, A.; Sette Jr, C.; et al. 2017. Producción de briquetas con residuos de cáscara de piñón manso (Jatropha curcas) y bagazo de caña de azúcar. Bosque 38: 527-533.

Rojas, A.; Ruales-Salcedo, A.; Velasco, F. 2018 a. Cinética de combustión de combustibles densificados de residuos del procesamiento de la uva isabella (Vitis labrusca L.). Revista Ingenierias Universidad de Medellín 17: 51-67.

Rojas, C.; Cea, M.; Rosas-Diaz, F.; et al. 2018b. Physical, Chemical and Mechanical Characterization of a Prototype Insulating Material Based on Eucalyptus Bark Fiber. leee Latin America Transactions 16: 2441-2446.

Romallosa, A.R.D.; Kraft, E. 2017. Feasibility of Biomass Briquette Production from Municipal Waste Streams by Integrating the Informal Sector in the Philippines. Resources-Basel 6: 1-19.

Rosa, P.; Sassanelli, C.; Urbinati, A.; et al. 2020. Assessing relations between Circular Economy and Industry 4.0: a systematic literature review. International Journal of Production Research 58: 1662-1687.

Sahoo, K.; Bilek, E.; Bergman, R.; et al. 2019. Technoeconomic analysis of producing solid biofuels and biochar from forest residues using portable systems. Applied Energy 235: 578-590.

Samadi, S.H.; Ghobadian, B.; Nosrati, M. 2020. Prediction and estimation of biomass energy from agricultural residues using air gasification technology in Iran. Renewable Energy 149: 1077-1091.

Sari, G.L.; Trihadiningrum, Y.; Ni'matuzahroh 2019. Bioremediation of Petroleum Hydrocarbons in Crude Oil Contaminated Soil from Wonocolo Public Oilfields using Aerobic Composting with Yard Waste and Rumen Residue Amendments. Journal of Sustainable Development of Energy Water and Environment Systems-Jsdewes 7: 482-492.

Sarkodie, S.A.; Adams, S.; Owusu, P.A.; et al. 2020a. Mitigating degradation and emissions in China: The role of environmental sustainability, human capital and renewable energy. Science of the Total Environment 719: 1-45.

Sarkodie, S.A.; Owusu, P.A.; Leirvik, T. 2020b. Global effect of urban sprawl, industrialization, trade and economic development on carbon dioxide emissions. Environmental Research Letters 15: 1-22.

Sawadogo, M.; Tanoh, S.; Sidibé, S.; et al. 2018. Cleaner production in Burkina Faso: Case study of fuel briquettes made from cashew industry waste. Journal of Cleaner Production 195: 1047-1056.

Sette, C.R.; da Cunha, T.Q.G.; Coneglian, A.; et al. 2020. Does the Presence of Bark in the Wood of FastGrowing Forest Species Significantly Change the Energy Potential? Bioenergy Research 13: 222-228.

Setter, C.; Silva, F.; Assis, M.; et al. 2020. Pirólisis lenta de briquetas de cáscara de café: caracterización de las fracciones sólidas y líquidas. Fuel 261: 1-11.

Shariat Panahi, H.; Dehhaghi, M.; Ok, Y.; et al. 2020. Una revisión exhaustiva del biochar diseñado: producción, características y aplicaciones medioambientales. Journal Pre-proofs 122462: 1-98.

Shevchenko, I.K.; Razvadovskaya, Y.V.; Marchenko, A.A 2019. Russian Textile Industry: Past and Present. Terra Economicus 17: 131-149.

Shirzad, M.; Kazemi Shariat Panahi, H.; Dashti, B.; et al. 2019. Una revisión exhaustiva sobre la generación de electricidad y los potenciales de reducción de emisiones de GEl a través de la digestión anaeróbica 
de los desechos agrícolas y ganaderos / mataderos en Irán. Renewable and Sustainable Energy Reviews 111: 571-594.

Soto, G.; Núñez, M. 2008. Fabricacion de pellets de carbonilla, usando aserrin de Pinus radiata (d. Don), como material aglomerante. Maderas. Ciencia y tecnología 10: 129-137.

Spirchez, C.; Lunguleasa, A.; Matei, M. 2018. Particularities of hollow-core briquettes obtained out of spruce and oak wooden waste. Maderas. Ciencia y tecnología 20: 139-152.

Stolarski, M.J.; Krzyianiak, M.; Warminski, K.; et al. 2019. Energy efficiency indices for lignocellulosic biomass production: Short rotation coppices versus grasses and other herbaceous crops. Industrial Crops and Products 135: 10-20.

Suvunnapob, S.; Ayudhya, B. I. N.; Kusuktham, B. 2015. A Study of Cotton Dust Mixed with Wood Dust for BioBriquette Fuel. Engineering Journal-Thailand 19: 57 70.

Teigiserova, D.; Hamelin, L.; Thomsen, M. 2020. Hacia una valorización transparente del excedente, el desperdicio y la pérdida de alimentos: definiciones aclaratorias, jerarquía del desperdicio de alimentos y papel en la economía circular. Science of the Total Environment 706: 1-50.

Titei, V.; Muntean, I.; Pasat, I.; et al. 2019. The quality of biomass and fuel pellets from Jerusalem artichoke stalks and wheat straw. Scientific Papers-Series aAgronomy 62: 567-572.

Tomeleri, J.; Valentim, L.; da Silva, J.; et al. 2017. Caracterização Química e Energética de Epicarpo Residual do Pinhão Manso (Jatropha curcas L.) e Briquete Produzido Rev. Virtual Quim. 9: 942-952.

Turemen, M.; Demir, A.; Ozdogan, E. 2019. Recycling and importance for textile industry. Pamukkale University Journal of Engineering SciencesPamukkale Universitesi Muhendislik Bilimleri Dergisi 25: 805-809.

Vargas, Y.; Pérez, L. 2018. Aprovechamiento de residuos agroindustriales para el mejoramiento de la calidad del ambiente. Revista Facultad de Ciencias Básicas 14: 59-72.

Verma, N.; Kumar, V. 2020. Utilization of bottle gourd vegetable peel waste biomass in cellulase production by Trichoderma reesei and Neurospora crassa. Biomass Conversion and Biorefinery 101007: 1-10.

Wang, T.F.; Wang, Z.X.; Zhai, Y.; et al. 2019. Effect of molasses binder on the pelletization of food waste hydrochar for enhanced biofuel pellets production. Sustainable Chemistry and Pharmacy 14: 1-8.

Weiss, B.D.; Glasner, C. 2018. Evaluation of the Process Steps of Pretreatment, Pellet Production and Combustion for an Energetic Utilization of Wheat Chaff. Frontiers in Environmental Science 6: 1-10.

Westerholm, M.; Liu, T.; Schnürer, A. 2020. Estudio comparativo de la producción de biogás altamente sólido a escala industrial a partir del desperdicio de alimentos: operación del proceso y microbiología. Bioresource Technology 304: 1-31.

Wu, L.X.; Lee, S.J. 2020. A Deep Learning-Based Strategy to the Energy Management-Advice for Time-of-Use Rate of Household Electricity Consumption. Journal of Internet Technology 21: 305-311.

Yaghin, R.G. 2020. Enhancing supply chain productionmarketing planning with geometric multivariate demand function (a case study of textile industry). Computers \& Industrial Engineering 140: 1-38.

Yang, H.; Ciais, P.; Santoro, M.; et al. 2020. Comparison of forest above-ground biomass from dynamic global vegetation models with spatially explicit remotely sensed observation-based estimates. Global Change Biology 101111: 1-16.

Yank, A.; Ngadi, M.; Kok, R. 2016. Physical properties of rice husk and bran briquettes under low pressure densification for rural applications. Biomass and Bioenergy 84: 22-30.

Yasin, S.; Curti, M.; Rovero, G.; et al. 2020. Spouted-Bed Gasification of Flame Retardant Textiles as a Potential Non-Conventional Biomass. Applied Sciences-Basel 10: 1-16.

Yuvaraj, A.; Karmegam, N.; Tripathi, S.; et al. 2020. Environment-friendly management of textile mill wastewater sludge using epigeic earthworms: Bioaccumulation of heavy metals and metallothionein production. Journal of Environmental Management 254: 1-10.

Zhai, Y.B.; Wang, T.F.; Zhu, Y.; et al. 2018. Production of fuel pellets via hydrothermal carbonization of food waste using molasses as a binder. Waste Management 77: 185-194.

Zhang, J.H.; Sun, G.; Liu, J.Y.; et al. 2020. Co-combustion of textile dyeing sludge with cattle manure: Assessment of thermal behavior, gaseous products, and ash characteristics. Journal of Cleaner Production 253: 1-39. 